\title{
Observations of high level of ozone at Qinghai Lake basin in the northeastern Qinghai-Tibetan Plateau, western China
}

\author{
Q. Y. Wang • R. S. Gao - J. J. Cao • J. P. Schwarz • \\ D. W. Fahey - Z. X. Shen • T. F. Hu • P. Wang • X. B. Xu • \\ R. -J. Huang
}

Received: 9 November 2014 / Accepted: 15 February 2015 /

Published online: 27 February 2015

(C) Springer Science+Business Media Dordrecht 2015

\begin{abstract}
Measurements of surface ozone $\left(\mathrm{O}_{3}\right)$, nitrogen oxides $\left(\mathrm{NO}_{\mathrm{x}}=\mathrm{NO}+\mathrm{NO}_{2}\right)$, carbon monoxide (CO), and dew point were made at Qinghai Lake (QHL), China, a basin in the remote Tibetan Plateau area, in October 2010 and October 2011. The $\mathrm{O}_{3}$ mixing ratio was found to be high with average of $41 \pm 9 \mathrm{ppb}$ in October 2010 and $57 \pm 10 \mathrm{ppb}$ in October 2011. The observed diurnal pattern of $\mathrm{O}_{3}$ mixing ratio was characterized by a minimum between 07:00 and 10:00 local standard time (LST) increasing $20 \mathrm{ppb}$ to a broad peak occurring
\end{abstract}

Electronic supplementary material The online version of this article (doi:10.1007/s10874-015-9301-9) contains supplementary material, which is available to authorized users.

Q. Y. Wang · J. J. Cao $\cdot$ T. F. Hu $\cdot$ P. Wang $\cdot$ R. .-J. Huang

Key Laboratory of Aerosol Chemistry and Physics, Institute of Earth Environment, Chinese Academy of Sciences, Xi'an 710061, China

R. S. Gao · J. P. Schwarz • D. W. Fahey

Chemical Sciences Division, Earth System Research Laboratory, National Oceanic and Atmospheric

Administration, Boulder, Colorado, USA

\section{J. J. Cao $(\bowtie)$}

Institute of Global Environmental Change, Xi'an Jiaotong University, Xi'an 710049, China

e-mail: cao@loess.llqg.ac.cn

\section{J. P. Schwarz • D. W. Fahey}

Cooperative Institute for Research in Environmental Sciences, University of Colorado, Boulder, Colorado, USA

\section{Z. X. Shen}

Department of Environmental Science and Engineering, Xi'an Jiaotong University, Xi'an 710049, China

X. B. Xu

Key Laboratory for Atmospheric Chemistry, Center for Atmospheric Watch and Services, Chinese Academy of Meteorological Sciences, CMA, Beijing 100081, China

R. .-J. Huang

Laboratory of Atmospheric Chemistry, Paul Scherrer Institute (PSI), 5232 Villigen, Switzerland

R. .-J. Huang $(\bowtie)$

Centre for Climate and Air Pollution Studies, Ryan Institute, National University of Ireland Galway,

University Road, Galway, Ireland

e-mail: Rujin.Huang@psi.ch 
between 13:00 and 18:00 LST. This diurnal pattern differs substantially from that observed at WMO's GAW Baseline Observatory located above the basin on Mount Waliguan, $\sim 130 \mathrm{~km}$ southeast of QHL. The elevated $\mathrm{O}_{3}$ mixing ratios observed in the afternoon are attributed to in situ photochemical production in the air trapped in the QHL basin by surrounding mountains. The low $\mathrm{O}_{3}$ mixing ratios observed in the morning are most likely due to surface removal in a shallow nocturnal boundary layer. The data indicate substantial impacts of pollution on air quality even in this remote area. The high $\mathrm{O}_{3}$ values observed in 2011 may cause observable damage to the vegetation, adding stress to an ecosystem ready under the threat of desertification.

Key words Ozone $\cdot$ Photochemical production · Qinghai-Tibetan Plateau

\section{Introduction}

Ozone $\left(\mathrm{O}_{3}\right)$ is a key atmospheric trace gas with climate and air quality importance (Guttikunda et al. 2005; Sitch et al. 2007; Selin et al. 2009; Cooper et al. 2012; Tie et al. 2013). Although $\sim 90 \%$ of $\mathrm{O}_{3}$ molecules are in the stratosphere, the remaining $10 \%$ of column $\mathrm{O}_{3}$ in the troposphere plays a critical role in influencing air quality and atmospheric chemistry (Cristofanelli et al. 2010). As the precursor of highly reactive hydroxyl $(\mathrm{OH})$ radicals, $\mathrm{O}_{3}$ regulates the oxidative capacity of the atmosphere determining the lifetime of many gases (Kumar et al. 2010). Due to its high chemical reactivity, elevated surface $\mathrm{O}_{3}$ is harmful to human health, natural ecosystems, and crop yields (Chameides et al. 1999; Mudway and Kelly 2000; Mauzerall and Wang 2001; Ashmore 2005; Ahmad et al. 2013). The budget of $\mathrm{O}_{3}$ in the troposphere is determined by the photochemistry involving volatile organic compounds (VOCs) and nitrogen oxides (NOx), downward transport from stratosphere, and dry deposition on the earth's surface (Crutzen 1973; Stohl et al. 2003; Adon et al. 2013). Additionally, $\mathrm{O}_{3}$ also plays an important role in the atmospheric radiation balance, particularly in the middle and upper troposphere, due to its strong ultraviolet absorption and greenhouse effect (Hassler et al. 2013; Antón et al. 2014).

The Tibetan Plateau is the highest plateau in the world (average height $\sim 4000 \mathrm{~m}$ above sea level), and exerts profound thermal and dynamic influences on regional and global climate (Chen et al. 2011). However, previous studies on $\mathrm{O}_{3}$ focused mainly on rural and urban China (e.g., Wang et al. 2006a; Jiang et al. 2012; Wang et al. 2014). Relatively limited effort has been made to understand trace gas levels in the Tibetan Plateau (e.g., Ye and Xu 2003; Tian et al. 2008; Li et al. 2009; Liu et al. 2010). Qinghai Lake (QHL: $36.32^{\circ}-37.12^{\circ} \mathrm{N}, 99.38^{\circ}-$ $100.45^{\circ} \mathrm{E}$ ), the largest lake in China, is located $\sim 3200 \mathrm{~m}$ above mean sea level (AMSL) in a semi-desert basin in the northeast of the Tibetan Plateau (Fig. 1). The QHL basin has a delicate ecosystem. High pollution, especially high $\mathrm{O}_{3}$ levels, can damage or suppress the growth of vegetation and contribute to desertification (Ashmore 2005; Ahmad et al. 2013). In the present study, we observed high $\mathrm{O}_{3}$ concentrations at QHL in October with a clear diurnal variation that was distinctly different to that observed at the Mount Waliguan Observatory despite their close proximity. We show below that the high $\mathrm{O}_{3}$ and distinct diurnal pattern at $\mathrm{QHL}$ are due to a combination of pollution, photochemistry and geography.

\section{Measurements}

Measurements were taken from 5 to 26 October, $2010\left(\mathrm{O}_{3}\right.$ and $\left.\mathrm{NO}_{\mathrm{x}}\right)$ and from 17 to 26 October, $2011\left(\mathrm{O}_{3}\right.$ and $\left.\mathrm{CO}\right)$ on the rooftop ( $\sim 15 \mathrm{~m}$ above ground level) of a sampling tower at 


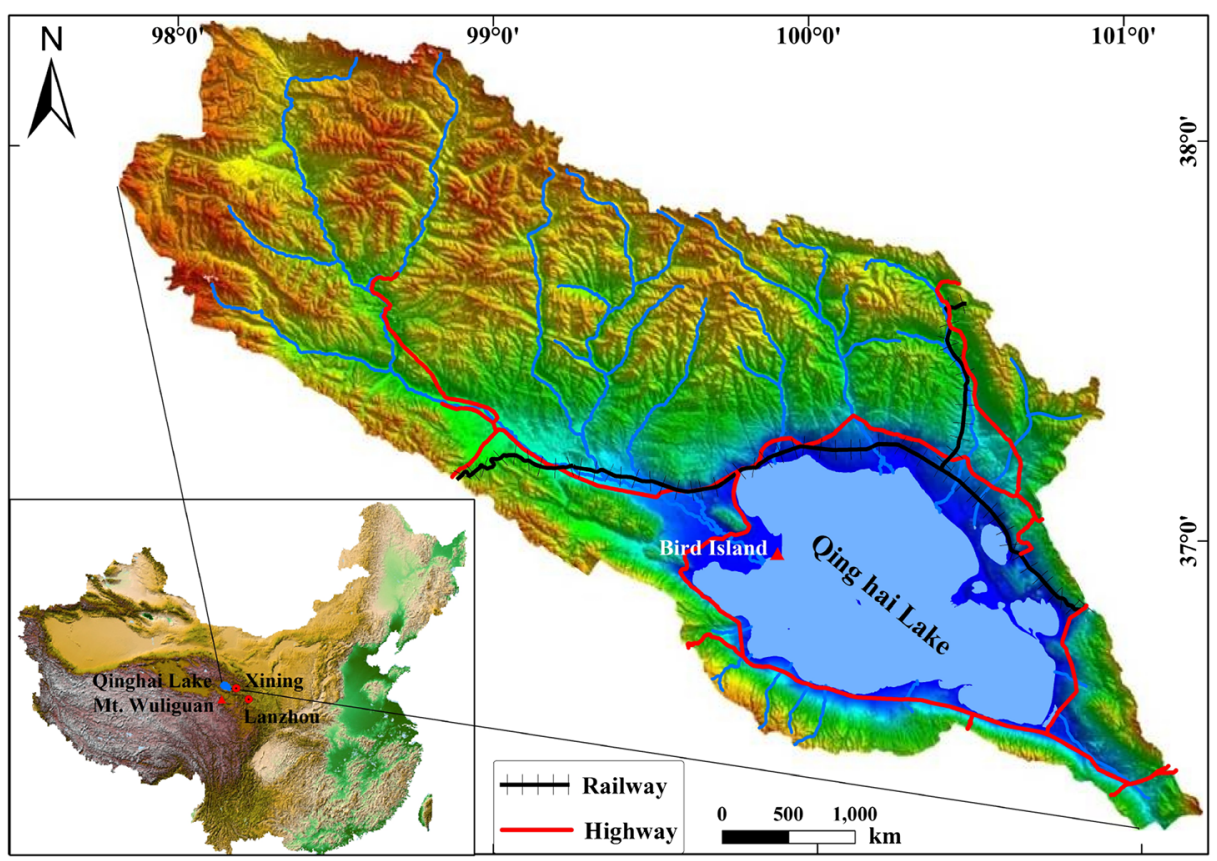

Fig. 1 The map of the sampling site at Qinghai Lake (QHL) and Mount Waliguan (WLG) as well as the surrounding regions

the "Bird Island" peninsula $\left(36.98^{\circ} \mathrm{N}, 99.88^{\circ} \mathrm{E}, \sim 3200 \mathrm{~m}\right.$ AMSL), which is located at the northwest section of the QHL shore as shown in Fig. 1. Five-minute average $\mathrm{O}_{3}$ mixing ratios were recorded using an ultraviolet (UV) photometer (Ecotech Model EC9810A Ozone Analyzer, Australia) that measures $\mathrm{O}_{3}$ in the range of $0-20,000 \mathrm{ppb}$ with a detection limit of $0.5 \mathrm{ppb}$. Five-minute average $\mathrm{NO}_{\mathrm{x}}$ was measured by a gas-phase chemiluminescence (Ecotech Model EC9841 Nitrogen Oxides Analyzer, Australia), where $\mathrm{NO}_{2}$ is converted to $\mathrm{NO}$ with a molybdenum catalytic converter followed by the detection of total NO. Because the molybdenum catalytic converter may convert other nitrogen oxides in addition to $\mathrm{NO}_{2}$ into $\mathrm{NO}$, the $\mathrm{NO}_{\mathrm{x}}$ reported here represents the upper limit of its true value. The detection limit is $0.5 \mathrm{ppb}$ of $\mathrm{NO}_{\mathrm{x}}$. These analyzers were calibrated before the field measurements by injecting standard gases of different concentrations. Five-minute average mixing ratios of $\mathrm{CO}$ gas were obtained using gas-filter correlation technology with infrared photometric detection (Ecotech Model EC9830T Carbon Monoxide Analyzer, Australia) with a detection limit of $20 \mathrm{ppb}$. Hourly dew point was measured at the Gangcha national reference climatological station, $\sim 45 \mathrm{~km}$ northeast from the sampling site. Surface $\mathrm{O}_{3}$ and dew point were also measured at the Mount Waliguan Observatory (WLG: $36.28^{\circ} \mathrm{N}, 100.90^{\circ} \mathrm{E}, 3816 \mathrm{~m}$ AMSL), the highest GAW (Global Atmospheric Watch) station, which is located $\sim 130 \mathrm{~km}$ to the southeast, and $\sim 600 \mathrm{~m}$ above the basin (Fig. 1), concurrently for comparison purpose.

\section{Results and discussion}

The time series of $\mathrm{O}_{3}, \mathrm{NO}_{\mathrm{x}}$ and $\mathrm{CO}$ measured at QHL are shown in Fig. 2. For comparison, $\mathrm{O}_{3}$ mixing ratios measured at WLG in October 2011 are also shown. The $\mathrm{O}_{3}$ mixing ratios ranged 


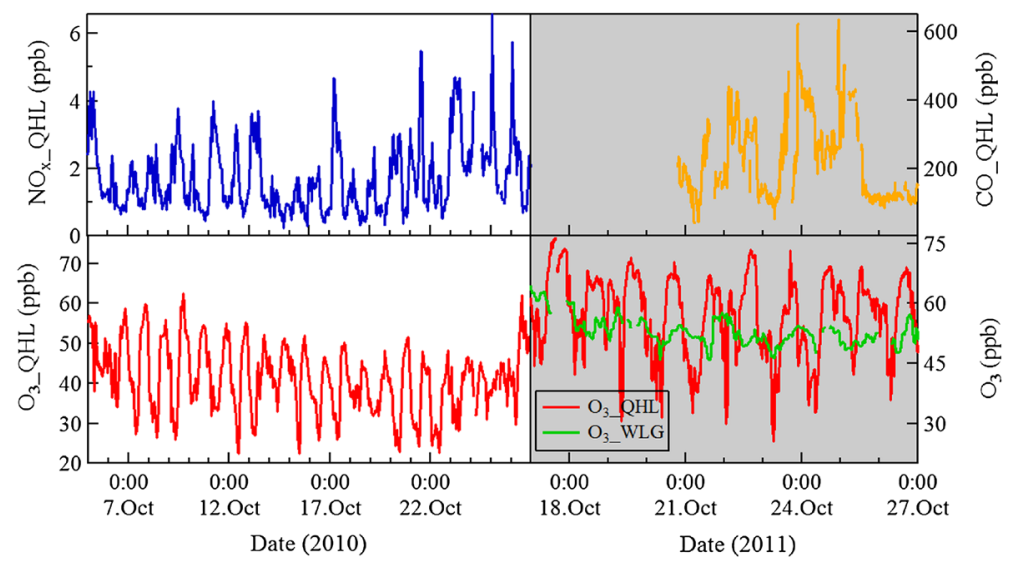

Fig. 2 Time series of 5-min averaged $\mathrm{O}_{3}$, NOx, and $\mathrm{CO}$ mixing ratios at Qinghai Lake (QHL) during 2010 and 2011. The time series of $\mathrm{O}_{3}$ mixing ratios at Mount Waliguan (WLG) during 2011 is also shown for comparison

from 22 to $62 \mathrm{ppb}$ with an average of $41 \pm 9 \mathrm{ppb}$ in October 2010, and from 26 to $77 \mathrm{ppb}$ with an average of $57 \pm 10 \mathrm{ppb}$ in October 2011. Although the absolute values show some difference, the diurnal patterns are consistent between October 2010 and October 2011, characterized by a clear diurnal pattern showing a rapid increase from daily minimum of $\sim 23-44 \mathrm{ppb}$ in the morning to daily maximum of $\sim 62-77 \mathrm{ppb}$ in the afternoon. Such large variation of $\mathrm{O}_{3}$ mixing ratio at QHL differs significantly from what observed at WLG where the $\mathrm{O}_{3}$ variation was only about $10 \mathrm{ppb}$. The daily minimal $\mathrm{O}_{3}$ mixing ratio at $\mathrm{QHL}$ was $\sim 25 \%$ lower than that at WLG, while the maximal $\mathrm{O}_{3}$ mixing ratio at QHL was $\sim 25 \%$ higher than that at WLG (Fig. 2). Furthermore, the diurnal $\mathrm{O}_{3}$ variation patterns at the two sites are different as discussed below, although the distance between two sites is only $\sim 130 \mathrm{~km}$.

Figure 3 shows the diurnal patterns of the average $\mathrm{O}_{3}$ mixing ratios and dew point for the entire measurement period at QHL and WLG, respectively. The $\mathrm{O}_{3}$ level at WLG showed minimal value ( $\sim 52 \mathrm{ppb})$ around noon local standard time (LST) and broad nocturnal maximum ( $\sim 56 \mathrm{ppb})$ between 19:00 and 02:00 LST. This diurnal pattern can be explained by the following mechanism: solar radiation heats the air adjacent to the mountain slopes during the day, resulting in an anabatic wind that brings low- $\mathrm{O}_{3}$ air from valleys below, and shortly after sunset, radiative cooling of the slopes cools the adjacent air, causing a katabatic wind that transports high- $\mathrm{O}_{3}$ air from the free troposphere to the station. This diurnal pattern is consistent with those observed in previous studies performed in spring and summer at WLG (Wang et al. 2006b; Xue et al. 2011). Note that the average value of $\mathrm{O}_{3}$ at WLG shown in Fig. $3 \mathrm{~b}$ is about $53 \mathrm{ppb}$, which is $\sim 10 \mathrm{ppb}$ higher than that measured in the same month in 1996 (Zhu et al. 2004).

In contrast, the $\mathrm{O}_{3}$ mixing ratios at QHL showed a trough between about 07:00 and 10:00 LST with a minimum value (33 ppb in 2010 and 43 ppb in 2011), followed by a sharp increase to reach daytime peak mixing ratio (49 ppb in 2010 and $67 \mathrm{ppb}$ in 2011) from about 13:00 to 18:00 LST. Following the daytime peak, the $\mathrm{O}_{3}$ mixing ratios declined continuously until the next early morning. The differences in $\mathrm{O}_{3}$ levels and their diurnal patterns between QHL and WLG are striking although both sites are remote and not far from each other $(\sim 130 \mathrm{~km})$. Compared to WLG, QHL is $\sim 130 \mathrm{~km}$ further away from the highly populated cities (Xining and Lanzhou, see Fig. 1). Therefore it is unlikely that an air parcel of a high level of $\mathrm{O}_{3}$ transported to QHL is not detected at WLG. Downward transport of stratospheric $\mathrm{O}_{3}$ could not 
(a) QHL

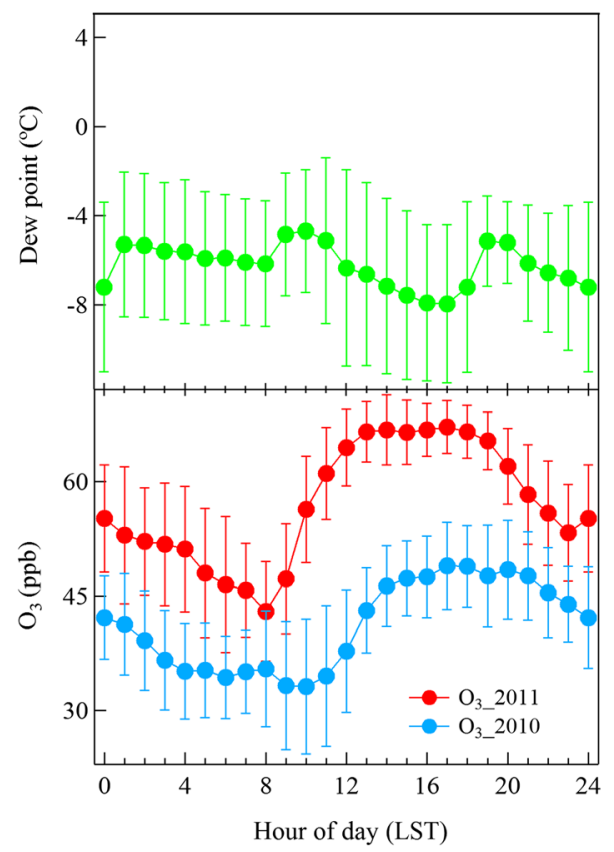

(b) WLG

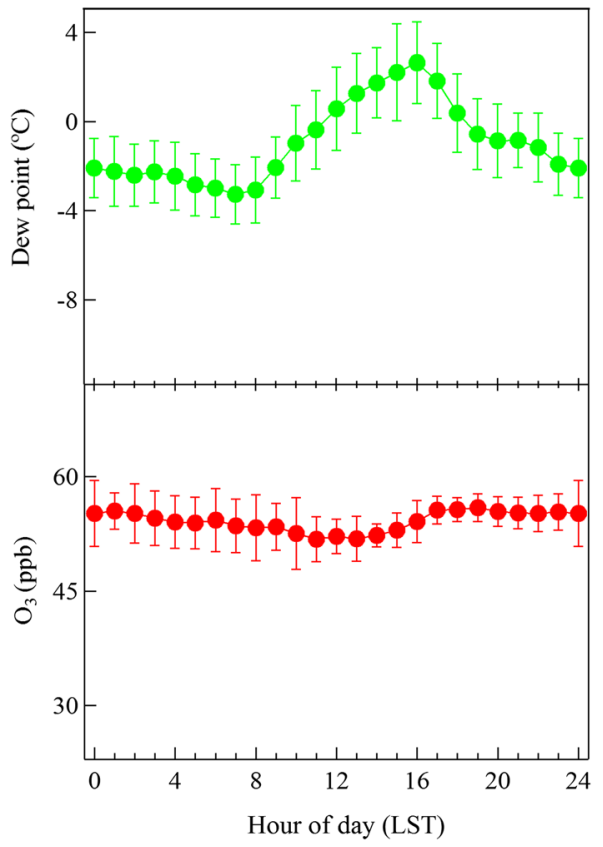

Fig. 3 Diurnal variations of $\mathrm{O}_{3}$ mixing ratios and dew point for the entire measurement period at (a) Qinghai Lake (QHL) and (b) Mount Waliguan (WLG), respectively. Vertical lines indicate one standard deviation. LST stands for local standard time

explain the observed difference between these two measurement sites, either. First, WLG is about $600 \mathrm{~m}$ higher than QHL, and therefore expected to experience the downward transport more often and intensely. However, the daily maximum $\mathrm{O}_{3}$ mixing ratios at WLG were around $25 \%$ lower than those at QHL. Second, measurements of $\mathrm{O}_{3}$ vertical profiles at Xining (the city $\sim 180 \mathrm{~km}$ away from QHL) showed the concentrations $<70 \mathrm{ppb}$ at the altitude below $8 \mathrm{~km}$ (Liu et al. 1997). Thus, downward transport of ozone rich air parcels to surface at QHL is very likely not a major contributor because there was no strong convection during the measurement periods. Figure S1 and Figure S2 of the supplementary data show that Aqua and Terra satellite images around local noon did not show significant convective clouds. Although dew point drops a few degrees in the afternoon (an indication of mixing of dry air from higher altitudes into the boundary layer, see Fig. 3), the $\mathrm{O}_{3}$ mixing ratios at QHL reach the maximum before the downwind transport begins.

In the troposphere, $\mathrm{O}_{3}$ is formed through photochemical reactions in the presence of $\mathrm{O}_{3}$ precursors, including the nitrogen oxides $\left(\mathrm{NO}_{\mathrm{x}}=\mathrm{NO}+\mathrm{NO}_{2}\right)$, carbon monoxide $(\mathrm{CO})$, and volatile organic carbons (VOCs) (Kumar et al. 2013). As shown in Fig. 2, significant amount of $\mathrm{NO}_{\mathrm{x}}$ and $\mathrm{CO}$ are found in the boundary layer. $\mathrm{The}^{\mathrm{NO}} \mathrm{x}$ and $\mathrm{CO}$ mixing ratios varied from 0.5 to $7 \mathrm{ppb}$ and from 34 to $634 \mathrm{ppb}$, respectively. Although this region is remote, each day thousands of diesel vehicles pass through the QHL basin via national highways surrounding the lake and these vehicles are likely the main source of $\mathrm{NO}_{\mathrm{x}}$ (and a $\mathrm{CO}$ source as well). Biofuel (including yak and sheep dung, firewood, and crop residues) is the main energy source in rural Qinghai, accounting for $\sim 80 \%$ of total household energy, of which $\sim 65 \%$ from burning yak and sheep dung (Ping et al. 2011). The basin also hosts a coalmine with unknown 

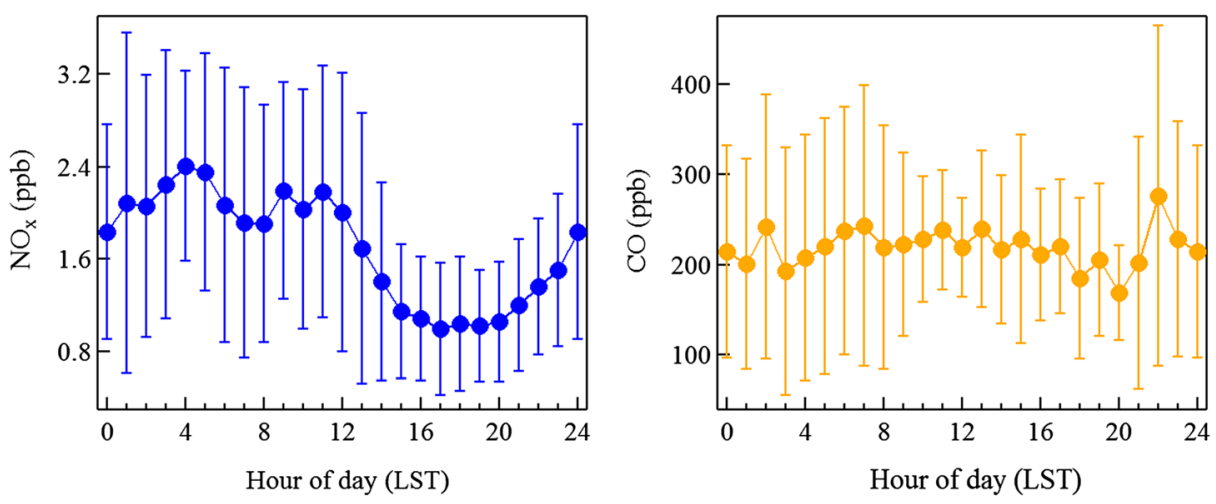

Fig. 4 Diurnal variations of NOx and CO mixing ratios at Qinghai Lake during October 2010 and 2011, respectively

power source and consumption. Trash burning is prevalent in this area. These pollution sources could contribute to significant amount of $\mathrm{CO}$ and VOCs as well as $\mathrm{NO}_{\mathrm{x}}$. The diurnal averages of $\mathrm{NO}_{\mathrm{x}}$ and $\mathrm{CO}$ are shown in Fig. 4. Average daily decrease in $\mathrm{NO}_{\mathrm{x}}$ from the morning to afternoon is about $1 \mathrm{ppb}$. This change is much smaller than the magnitude of $\mathrm{O}_{3}$ increase $(>10 \mathrm{ppb})$, indicating that the sharp daily increase of $\mathrm{O}_{3}$ is not simply due to $\mathrm{NO}_{2}$ photolysis.

It is likely that the high $\mathrm{O}_{3}$ mixing ratio and its distinct diurnal pattern at QHL are consequence of a combination of geographic location, meteorological conditions, and in situ photochemistry. The large QHL basin is only aerated with fresh air at surface when the boundary layer is higher than the surrounding mountains. The dew point measurements suggest that this only happens after late morning, and only lasts until early evening. Surface air is trapped in the basin for the rest of time. After sunset, a very shallow inversion surface layer may develop (Whiteman et al. 2008; 2010). $\mathrm{O}_{3}$ trapped in this layer may be gradually consumed by a combination of dry deposition and titration by NO, but quickly replenished in the morning as the boundary layer height grows. Throughout the daytime $\mathrm{O}_{3}$ is produced photochemically in the basin; and may be transported to the free troposphere only when the boundary layer height is above the surrounding mountains, which is about $600-800 \mathrm{~m}$ above the lake. Overall, the situation encountered at QHL basin is similar to the Upper Green River Basin of Wyoming reported by Schnell et al. (2009) and Carter and Seinfeld (2012).

\section{Concluding remarks}

High mixing ratios of $\mathrm{O}_{3}$ and a distinct diurnal pattern have been observed at Qinghai Lake (QHL), China. The daily $\mathrm{O}_{3}$ concentrations varied from 26 to $77 \mathrm{ppb}$, much larger than those observed at the nearby GAW Waliguan (WLG) station. The difference in diurnal cycle of $\mathrm{O}_{3}$ between these two locations is striking even though the distance between these two sites are only $\sim 130 \mathrm{~km}$, suggesting the combined effects from local geography, meteorology, and air pollution. The diurnal variation of $\mathrm{QHL} \mathrm{O}_{3}$ can be attributed to in situ photochemical production during the day and dry deposition at night. Emissions from heavy duty trucks around QHL could be an important source responsible for the high $\mathrm{O}_{3}$ levels at the QHL region. Our results suggest that further measurements (e.g., speciated reactive nitrogen compounds and volatile organic carbons) are needed for a better understanding of $\mathrm{O}_{3}$ pollution at the pristine Tibetan Plateau. 
Acknowledgments This project is supported by the Natural Science Foundation of China (NSFC 41230641) and the Ministry of Science and Technology (2012BAH31B03). RSG, JPS, and DWF were supported by the NOAA Atmospheric Composition and Climate Program and the NOAA Health of the Atmosphere Program. The authors thank the Qinghai Institute of Meteorological Science for providing the meteorological data.

\section{References}

Adon, M., Galy-Lacaux, C., Delon, C., Yoboue, V., Solmon, F., Tchuente, A.T.K.: Dry deposition of nitrogen compounds $\left(\mathrm{NO}_{2}, \mathrm{HNO}_{3}, \mathrm{NH}_{3}\right)$, sulfur dioxide and ozone in west and central African ecosystems using the inferential method. Atmos. Chem. Phys. 13, 11351-11374 (2013)

Ahmad, M.N., Büker, P., Khalid, S., Berg, L.V.D., Shah, H.U., Wahid, A., Emberson, L., Power, S.A., Ashmore, M.: Effects of ozone on crops in north-west Pakistan. Environ. Pollut. 174, 244-249 (2013)

Antón, M., Mateos, D., Roman, Valenzuela, A., Alados-Arboledas, L., Olmo, F.J.: A method to determine the ozone radiative forcing in the ultraviolet range from experimental data. J. Geophys. Res. 119, 1860-1873 (2014)

Ashmore, M.: Assessing the future global impacts of ozone on vegetation. Plant Cell Environ. 28, 949-964 (2005)

Carter, W.P.L., Seinfeld, J.H.: Winter ozone formation and VOC incremental reactivities in the Upper Green River Basin of Wyoming. Atmos. Environ. 50, 255-266 (2012)

Chameides, W.L., Li, X., Tang, X., Zhou, X., Chao, L., Kiang, C.S., John, J.S., Saylor, R.D., Liu, S.C., Lam, K.S., Wang, T., Giorgi, F.: Is ozone pollution affecting crop yields in China? Geophys. Res. Lett. 26, 867870 (1999)

Chen, X.L., Ma, Y.M., Kelder, H., Su, Z., Yang, K.: On the behaviour of the tropopause folding events over the Tibetan Plateau. Atmos. Chem. Phys. 11, 5113-5122 (2011)

Cooper, O.R., Gao, R.S., Tarasick, D., Leblanc, T., Sweeney, C.: Long-term ozone trends at rural ozone monitoring sites across the United States, 1990-2010. J. Geophys. Res. 117, D22307 (2012). doi:10.1029/ 2012JD018261

Cristofanelli, P., Bracci, A., Sprenger, M., Marinoni, A., Bonafe, U., Calzolari, F., Duchi, R., Laj, P., Pichon, J.M., Roccato, F., Venzac, H., Vuillermoz, E., Bonasoni, P.: Tropospheric ozone variations at the Nepal climagte observatory-pyramid (Himalayas, $5079 \mathrm{~m}$ a.s.1.) and influence of deep stratospheric intrusion events. Atmos. Chem. Phys. 10, 6537-6549 (2010)

Crutzen, P.: A discussion of the chemistry of some minor constituents in the stratosphere and troposphere. Pure Appl. Geophys. 106, 1385-1399 (1973)

Guttikunda, S.K., Tang, Y., Carmichael, G.R., Kurata, G., Pan, L., Streets, D.G., Woo, J.H., Thongboonchoo, N., Fried, A.: Impacts of Asian megacity emissions on regional air quality during spring 2001. J. Geophys. Res. 110, D20301 (2005). doi:10.1029/2004JD004921

Hassler, B., Young, P.J., Portmann, R.W., Bodeker, G.E., Daniel, J.S., Rosenlof, K.H., Solomon, S.: Comparison of three vertically resolved ozone data sets: climatology, trends and radiative forcings. Atmos. Chem. Phys. 13, 5533-5550 (2013)

Jiang, F., Zhou, P., Liu, Q., Wang, T., Zhuang, B., Wang, X.: Modeling tropospheric ozone formation over East China in springtime. J. Atmos. Chem. 69, 303-319 (2012)

Kumar, R., Naja, M., Venkataramani, S., Wild, O.: Variations in surface ozone at Nainital: a high-altitude site in the central Himalayas. J. Geophys. Res. 115, D16302 (2010). doi:10.1029/2009JD013715

Kumar, A., Wu, S., Weise, M., Honrath, R., Owen, R., Helmig, D., Kramer, L., Val Martin, M., Li, Q.: Freetroposphere ozone and carbon monoxide over the North Atlantic for 2001-2011. Atmos. Chem. Phys. 13, 12537-12547 (2013)

Li, J., Wang, Z., Akimoto, H., Tang, J., Uno, I.: Modeling of the impacts of China's anthropogenic pollutants on the surface ozone summer maximum on the northern Tibetan Plateau. Geophys. Res. Lett. 36, L24802 (2009). doi:10.1029/2009GL041123

Liu, Q., Zheng, X., Luo, C., Ding, G., Li, X., Zhou, X.: Ozone vertical profile characteristics over Qinghai Plateau measured by electrochemical concentration cell ozonesondes. Adv. Atmos. Sci. 14, 481-490 (1997)

Liu, C., Liu, Y., Cai, Z., Gao, S., Bian, J., Liu, X., Chance, K.: Dynamic formation of extreme ozone minimum events over the Tibetan Plateau during northern winters 1987-2001. J. Geophys. Res. 115, D18311 (2010). doi:10.1029/2009JD013130

Mauzerall, D.L., Wang, X.P.: Protecting agricultural crops from the effects of tropospheric ozone exposure: reconciling science and standard setting in the United States, Europe, and Asia. Annu. Rev. Energy Environ. 26, 237-268 (2001)

Mudway, I., Kelly, F.: Ozone and the lung: a sensitive issue. Mol. Asp. Med. 21, 1-48 (2000) 
Ping, X., Jiang, Z., Li, C.: Status and future perspectives of energy consumption and its ecological impacts in the Qinghai-Tibet region. Renew. Sust. Energ. Rev. 15, 514-523 (2011)

Schnell, R.C., Oltmans, S.J., Neely, R.R., Endres, M.S., Molenar, J.V., White, A.B...: Rapid photochemical production of ozone at high concentrations in a rural site during winter. Nat. Geosci. 2, 120-122 (2009)

Selin, N.E., Wu, S., Nam, K.M., Reilly, J.M., Paltsev, S., Prinn, R.G., Webster, M.D.: Global health and economic impacts of future ozone pollution. Environ. Res. Lett. 4, 044014 (2009). doi:10.1088/17489326/4/4/044014

Sitch, S., Cox, P., Collins, W., Huntingford, C.: Indirect radiative forcing of climate change through ozone effects on the land-carbon sink. Nature 448, 791-794 (2007)

Stohl, A., Bonasoni, P., Cristofanelli, P., Collins, W., Feichter, J., Frank, A., Forster, C., Gerasopoulos, E., Gäggeler, H., James, P.: Stratosphere-troposphere exchange: a review, and what we have learned from STAC CATO. J. Geophys. Res. 108, D12 8516 (2003). doi:10.1029/2002JD002490

Tian, W., Chipperfield, M., Huang, Q.: Effects of the Tibetan Plateau on total column ozone distribution. Tellus 60B, 622-635 (2008)

Tie, X., Geng, F., Guenther, A., Cao, J., Greenberg, J., Zhang, R., Apel, E., Li, G., Weinheimer, A., Chen, J., Cai, C.: Megacity impacts on regional ozone formation: observations and WRF-Chem modeling for the MIRAGE-Shanghai field campaign. Atmos. Chem. Phys. 13, 5655-5669 (2013)

Wang, H., Zhou, L., Tang, X.: Ozone concentrations in rural regions of the Yangtze Delta in China. J. Atmos. Chem. 54, 255-265 (2006a)

Wang, T., Wong, H.L.A., Tang, J., Ding, A., Wu, W., Zhang, X.: On the origin of surface ozone and reactive nitrogen observed at a remote mountain site in the northeastern Qinghai-Tibetan Plateau, western China. J. Geophys. Res. 111, D08303 (2006b). doi:10.1029/2005JD006527

Wang, Y.H., Hu, B., Ji, D.S., Liu, Z.R., Tang, G.Q., Xin, J.Y., Zhang, H.X., Song, T., Wang, L.L., Gao, W.K., Wang, X.K., Wang, Y.S.: Ozone weekend effects in the Beijing-Tianjin-Hebei metropolitan area. China. Atmos. Chem. Phys. 14, 2419-2429 (2014)

Whiteman, C.D., Muschinski, A., Zhong, S., Fritts, D., Hoch, S.W., Hahnenberger, M., Yao, W., Hohreiter, V., Behn, M., Cheon, Y., Clements, C.B., Horst, T.W., Brown, W.O.J., Oncley, S.P.: METCRAX 2006 meteorological experiments in Arizona's Meteor Crater. Bull. Am. Meteorol. Soc. 89, 1665-1680 (2008)

Whiteman, C.D., Hoch, S.W., Lehner, M., Haiden, T.: Nocturnal cold-air intrusions into a closed basin: observational evidence and conceptual model. J. Appl. Meteorol. Climatol. 49, 1894-1905 (2010)

Xue, L.K., Wang, T., Zhang, J.M., Zhang, X.C., Deliger, P.C.N., Ding, A.J., Zhou, X.H., Wu, W.S., Tang, J., Zhang, Q.Z., Wang, W.X.: Source of surface ozone and reactive nitrogen speciation at Mount Waliguan in western China: new insights from the 2006 summer study. J. Geophys. Res. 116, D07306 (2011). doi:10. 1029/2010JD014735

Ye, Z., Xu, Y.: Climate characteristics of ozone over Tibetan Plateau. J. Geophys. Res. 108(D20), 4654 (2003). doi:10.1029/2002JD003139

Zhu, B., Akimoto, H., Wang, Z., Sudo, K., Tang, J., Uno, I.: Why does surface ozone peak in summertime at Waliguan? Geophys. Res. Lett. 31, L17104 (2004). doi:10.1029/2004GL020609 